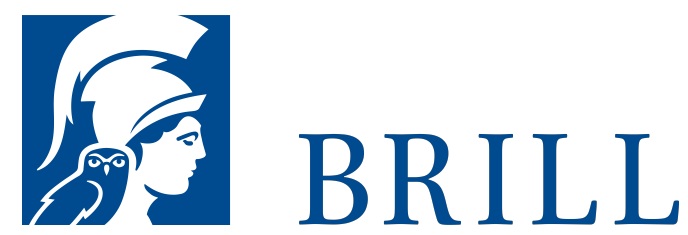

\title{
Mit Hitler im Gespräch
}

Blenden - überzeugen - wüten

Author: Karl-Günter Zelle

Hitler überzeugte: Fachleute verzichteten auf ihre begründete Meinung und schlossen sich ihm an. Ausländische Politiker staunten, wie staatsmännisch und sachkundig er verhandelte. Hitlers Selbstgewissheit und seine kühnen Projektionen blendeten. Aber nicht immer gewann er seine Wortgefechte. Hitlers Lügen und Täuschungen konnten offenbar werden - das zerstörte Vertrauen. Seine Wutanfälle waren meist Mittel der Macht, gelegentlich aber auch Ausdruck der Verzweiflung. Karl-Günter Zelle untersucht eine Vielzahl von Gesprächen Hitlers mit Diplomaten, Generälen, Anhängern, Unabhängigen. Er entdeckt das reiche sprachliche und gestische Instrumentarium, mit dem dieser seine Gesprächserfolge erzielte.

Zelle zeigt aber auch die Widersprüche auf, in denen Hitler lebte: Er erdachte Wunschträume und wollte sie verwirklichen. Aber es gab auch depressive Phasen mit Realismus und sogar Todesgedanken. Hinter den offensichtlichen Zielen Hitlers erscheinen seine verborgenen.

Psychologische Exkurse eröffnen dem Leser eine zusätzliche Dimension der Deutung. Mit höchster Aufmerksamkeit für das Detail zeichnet Karl-Günter Zelle die Nahsicht eines Diktators im Gespräch.

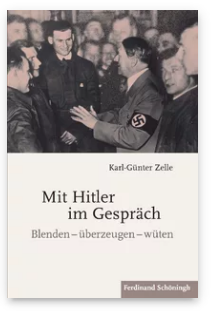

Pages: 335

Seiten, $11 \mathrm{~s} / \mathrm{w}$

Abb., 1 s/w Tab.

Language:

German

Subjects:

Modern History, History

Publisher: Brill |

Schöningh

E-Book (PDF)

Released online:

o5 Oct 2017

ISBN: $978-3^{-}$

657-78659-6

List price

Hardback

Publication date: 29 Sep 2017

ISBN: $978-3^{-}$ 5o6-78659-3

List price 
Karl-Günter Zelle ist als unabhängiger Historiker tätig. Von ihm erschien bei Schöningh: Hitlers zweifelnde Elite: Goebbels Göring - Himmler - Speer.

For more information see brill.com

Order information: Order online at brill.com +44 330 333 0049 | customerservices@brill.com Submission information: brill.com/authors

Titles published by Brill | Fink, Brill | mentis or Brill| Schöningh: +49(o)71 5413279216 | brill@brocom.de 